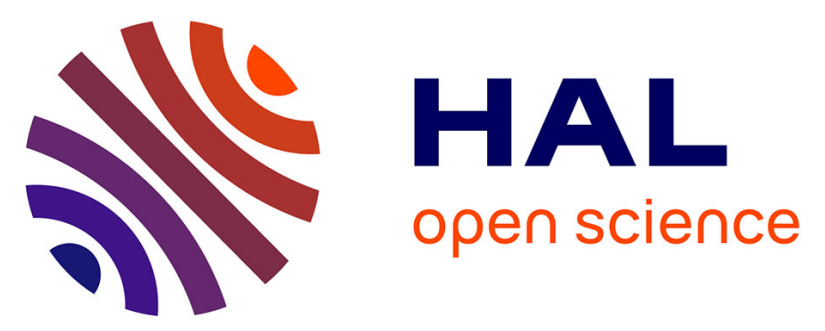

\title{
The Selective Estrogen Receptor Modulator 4-Hydroxy Tamoxifen Induces G1 Arrest and Apoptosis of Multiple Myeloma Cell Lines
}

Juliette Gauduchon, Fabrice Gouilleux, Sébastien Maillard, Véronique

Marsaud, Michel Renoir, Brigitte Sola

\section{To cite this version:}

Juliette Gauduchon, Fabrice Gouilleux, Sébastien Maillard, Véronique Marsaud, Michel Renoir, et al.. The Selective Estrogen Receptor Modulator 4-Hydroxy Tamoxifen Induces G1 Arrest and Apoptosis of Multiple Myeloma Cell Lines. Annals of the New York Academy of Sciences, 2003, 1010 (1), pp.321-325. 10.1196/annals.1299.057 . hal-02427345

\section{HAL Id: hal-02427345 \\ https://hal-univ-tours.archives-ouvertes.fr/hal-02427345}

Submitted on 3 Nov 2021

HAL is a multi-disciplinary open access archive for the deposit and dissemination of scientific research documents, whether they are published or not. The documents may come from teaching and research institutions in France or abroad, or from public or private research centers.
L'archive ouverte pluridisciplinaire HAL, est destinée au dépôt et à la diffusion de documents scientifiques de niveau recherche, publiés ou non, émanant des établissements d'enseignement et de recherche français ou étrangers, des laboratoires publics ou privés. 


\title{
The Selective Estrogen Receptor Modulator 4-Hydroxy Tamoxifen Induces G1 Arrest and Apoptosis of Multiple Myeloma Cell Lines
}

\author{
JULIETTE GAUDUCHON,${ }^{a}$ FABRICE GOUILLEUX, ${ }^{b}$ SÉBASTIEN MAILLARD,${ }^{c}$ \\ VÉRONIQUE MARSAUD, ${ }^{c}$ MICHEL J. RENOIR, ${ }^{c}$ AND BRIGITTE SOLA ${ }^{a}$ \\ ${ }^{a}$ UPRES-EA 2128, UFR de Médecine, Université de Caen, Caen, France \\ ${ }^{b}$ Laboratoire d'Immunologie, UFR de Médecine, Université Jules Verne, Amiens, France \\ ${ }^{c}$ Laboratoire de Pharmacologie Cellulaire et Moléculaire des Anti-cancéreux, \\ CNRS UMR 8612, UFR de Pharmacie, Châtenay-Malabry, France
}

\begin{abstract}
Multiple myeloma (MM) is an incurable hematological malignancy for which new therapeutic strategies should be envisaged. The selective estrogen receptor modulator (SERM), 4-hydroxy tamoxifen (4-OHTam), in the range of 1 to $10 \mu M$, was able to impair the cell proliferation of MM cell lines. This was achieved by blocking cells at the G1 phase of the cell cycle and by inducing apoptosis. This cellular response was observed in five out of six tested cell lines, all five expressing both $\alpha$ and $\beta$ estrogen receptor forms. No modifications of Bcl-2, Bcl-X, and Bax levels were observed, as well as no changes in Pi3K/Akt and JAK/STAT pathways that are often constitutively active in these cells. The signalization of 4-OHTam-induced cell death needs further investigation.
\end{abstract}

KEYWORDS: multiple myeloma; cell cycle; apoptosis; Bcl-2 family; p53; survival pathway

\section{INTRODUCTION}

Multiple myeloma (MM) is a B-cell malignancy characterized by the clonal expansion of plasma cells in the bone marrow and the occurrence of bone destruction. ${ }^{1}$ Accounting for approximately $1-2 \%$ of all human cancers and $10 \%$ of hematological malignancies, $\mathrm{MM}$ is a relatively frequent disease. ${ }^{1}$ Although high-dose chemotherapy associated with autologous hematopoietic stem cell transplantation has improved overall patient survival, the prognosis is still poor and new therapeutic strategies have to be designed. ${ }^{2}$ In two recent reports, tamoxifen and toremifene, active as efficient antiestrogens (AE) in the treatment of estrogen-dependent breast cancer, induced growth inhibition and apoptosis of MM cell lines and MM patients. ${ }^{3,4}$ However, the apoptosis-related molecular events are unclear. In order to get new insights, we analyzed the response of six MM cell lines towards 4-hydroxy tamoxifen (4OHTam) treatment.

Address for correspondence: Brigitte Sola, UPRES-EA 2128, UFR de Médecine, CHU Côte de Nacre, 14032 Caen Cedex, France. Voice: +33-2-31-06-82-25; fax: +33-2-31-47-40-84.

sola@medecine.unicaen.fr

Ann. N.Y. Acad. Sci. 1010: 321-325 (2003). (C) 2003 New York Academy of Sciences. doi: 10.1196/annals.1299.057 


\section{MATERIALS AND METHODS}

LP1, U266, NCI H929, and Karpas 620 MM cell lines have been described previously. ${ }^{5}$ CAC-2 and CAC- 6 have been derived in our laboratory and exhibited key features of MM cell lines (data not shown). Cells were maintained in RPMI 1640 and supplemented with $10 \%$ heat-inactivated fetal calf serum (FCS), $100 \mathrm{U} / \mathrm{mL}$ penicillin, $100 \mu \mathrm{g} / \mathrm{mL}$ streptomycin, and $2 \mathrm{mM}$ L-glutamine. In experiments using 4-OHTam, cells were cultured in phenol red-free RPMI 1640 medium supplemented with charcoal-treated, inactivated FCS in order to eliminate estrogen agonistic or antiagonistic activities. For cell proliferation and viability determinations, cells excluding trypan blue were counted in a hemocytometer at different time intervals. Cell viability was assayed using CellTiter 96 Aqueous One Solution ${ }^{\circledR}$ (Promega, France) as recommended by the supplier. Cell cycle analysis and apoptosis determination were realized after propidium iodide staining and fluorescent cell sorter examination. Western blots were obtained after electrophoresis of whole-cell extract proteins, transfer onto nylon membranes, and immunodetection.

\section{RESULTS}

We first analyzed the effects of concentrations of 4-OHTam varying from 0.01 to $100 \mu \mathrm{M}$ on the six cell lines (LP1, CAC-2, CAC-6, NCI H929, U266, and Karpas 620) using an XTT assay (see MATERIALs AND METHODs). The tests determined that concentrations higher than $10 \mu \mathrm{M}$ were highly toxic and led to cell death after a 24- or 48-h treatment (data not shown). We then studied the effects of 4-OHTam $(0-10 \mu \mathrm{M})$ on cell proliferation and found in all cases, except Karpas 620, that the 4-OHTam impaired cell proliferation. As exemplified for the LP1 and NCI H929 cell lines (FIG. 1A), this inhibition correlated with the AE concentration used.

As demonstrated by cytofluorometric analysis, the decrease of cell proliferation was the result of a block at the G1 phase of the cell cycle, as well as the induction of apoptotic cell death (exemplified for LP1 and NCI H929; FIG. 1B). Again, both the percentage of cells accumulated in G1 and the percentage of apoptotic cells correlated with the AE concentration (TABLE 1).

TABLE 1. Results obtained with each MM cell line

\begin{tabular}{|c|c|c|c|c|c|c|}
\hline \multirow[b]{2}{*}{ MM cell line } & \multicolumn{3}{|c|}{ Increase in sub-G1 fraction } & \multicolumn{3}{|c|}{ Increase in $\mathrm{G} 1$ fraction } \\
\hline & $1 \mu \mathrm{M}$ & $5 \mu \mathrm{M}$ & $10 \mu \mathrm{M}$ & $1 \mu \mathrm{M}$ & $5 \mu \mathrm{M}$ & $10 \mu \mathrm{M}$ \\
\hline LP1 & 1 & - & 7 & 2 & 10 & 19 \\
\hline $\mathrm{CAC}-2$ & - & 1 & 8 & - & 9 & 20 \\
\hline CAC- 6 & - & 6 & nd & 6 & 9 & nd \\
\hline NCI H929 & 1 & 1 & 19 & - & 9 & 7 \\
\hline U299 & - & 4 & 9 & - & 9 & 18 \\
\hline Karpas 620 & - & - & - & - & - & - \\
\hline
\end{tabular}

Note: The increase in sub-G1 and G1 fractions was calculated as the difference between the percentage of treated vs. nontreated cells in each fraction; -, no increase; nd, not done. 
A.

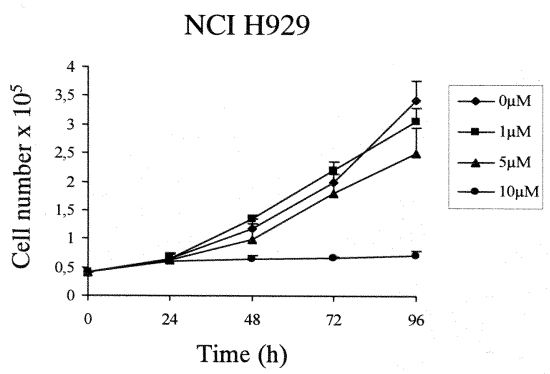

B.

nt

LP

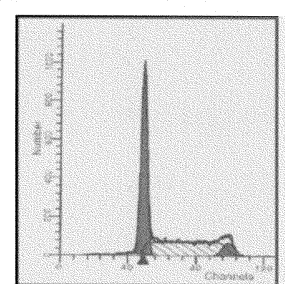

$\%$ subG1 : 2.7

$\% \mathrm{G} 1: \quad 49.6$
+4-OHTam

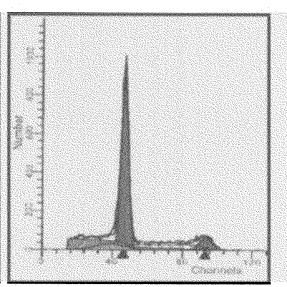

9.6

69.2
LP1

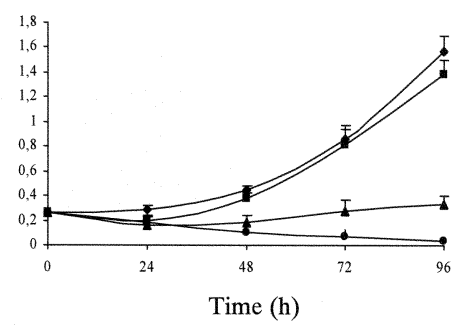

NCI H929 +4-OHTam

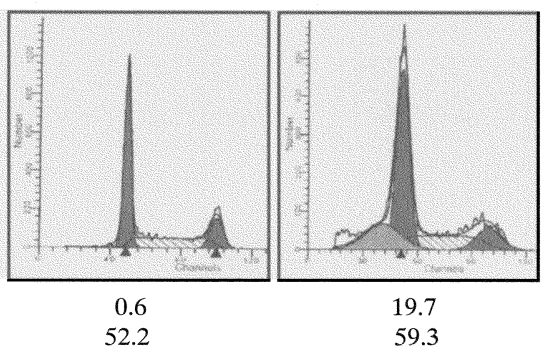

FIGURE 1. Effects of 4-OHTam on MM cell line proliferation and apoptosis. (A) Exponentially growing cells were treated, or not for controls, with various concentrations of 4-OHTam (1-10 $\mu \mathrm{M})$. At various times (24-96 h), viable cells, excluding trypan blue, were enumerated. Experiments were done in triplicate. Representative proliferation curves of NCI H929 and LP1 cell lines are presented. (B) MM cells were treated for $48 \mathrm{~h}$ with various concentrations of 4-OHTam $(0-10 \mu \mathrm{M})$. They were then stained with propidium iodide and sorted with the FACScalibur cytometer. Ten thousand events were acquired for each sample, and the results were analyzed with CellQuest v.1.1.2 and ModFit LT v.1.01 softwares. Representative profiles obtained with LP1 and NCI H929 cells are presented. The percentages of cells in the sub-G1 and G1 fractions are noted under the graphs.

The cell lines responding to 4-OHTam treatment possessed both $\alpha$ and $\beta$ estrogen receptors (ER), which were absent on Karpas 620 cells (FIg. 2A). The apoptotic cell death elicited by the 4-OHTam did not require $\mathrm{Bcl}-2, \mathrm{Bcl}-\mathrm{X}$, or Bax proteins (FIG. 2B). The Pi3K/Akt pathway constitutively activated in MM cell lines, despite a normal level of PTEN, was not modified by 4-OHTam treatment, nor was the JAK/ STAT3 pathway constitutively activated in CAC-2, LP1, and U266 (data not shown; FIG. 2C). 
A.

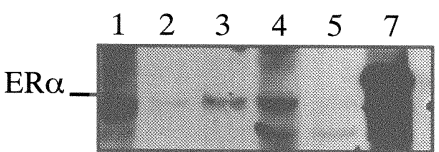

1. LP1

2. $\mathrm{CAC}-2$

$\begin{array}{lllllll}7 & 1 & 2 & 6 & 3 & 4 & 5\end{array}$

3. U266

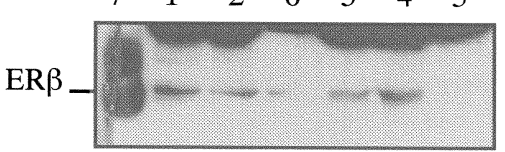

4. CAC-6

5. Karpas 620

6. NCI H929

7. Lysate

B.

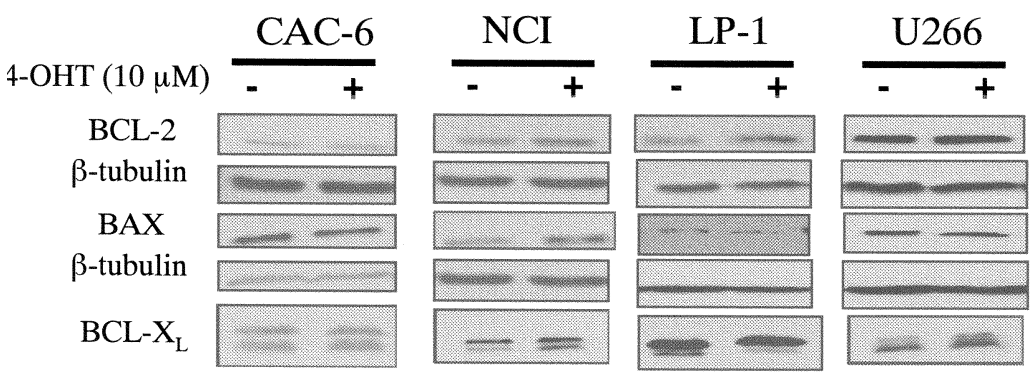

C.
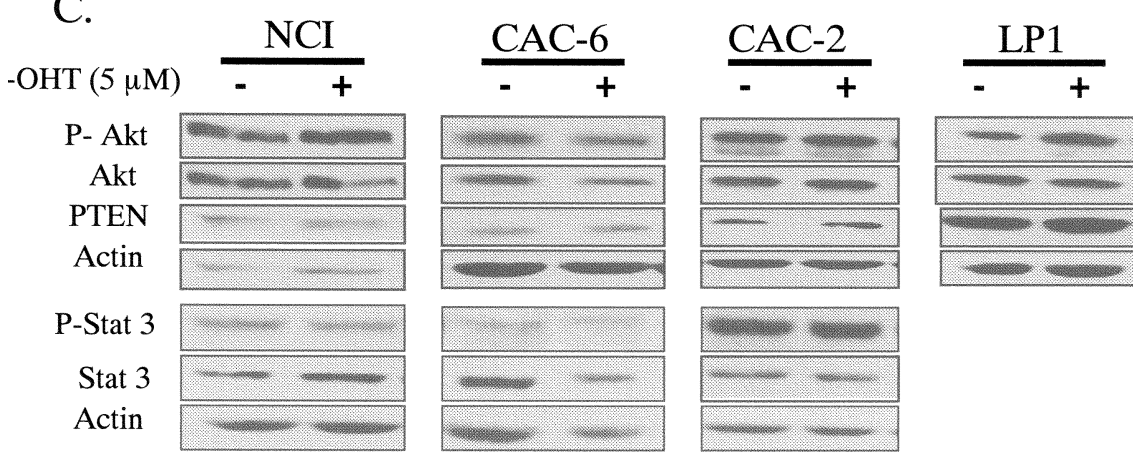

FIGURE 2. Expression of estrogen receptors and modulation of signaling molecules by the 4-OHTam. (A) Total cell extracts were prepared from MM cells that were grown in phenol red-free medium containing stripped FCS for $48 \mathrm{~h}$. Aliquots (100 $\mu \mathrm{g}$ of proteins) were separated on an $8 \%$ SDS-PAGE, transferred onto a PVDF membrane, and blotted with D12 anti-ER mouse antibody (Santa Cruz Lab.) or with E8 anti-ER $\beta$ rabbit antibody (a gift of G. Greene). As a control, $80 \mathrm{ng}$ of $E R \alpha$ and $E R \beta$ translated in rabbit reticulocyte lysates were used (lane 7). (B) Western blots, realized as in part A, were performed with the following antibodies: anti-Bcl-2 from Dako; anti-Bcl-X, anti-Bax, and antitubulin from Santa Cruz Biotech. (C) Western blots were performed with the following antibodies: antiphospho-Akt, anti-Akt, and anti-PTEN from Cell Signaling; anti-phospho-STAT3, anti-STAT3, and antiactin from Santa Cruz Biotech. 


\section{DISCUSSION}

The 4-OHTam inhibits cell proliferation of ER-expressing myeloma cells by blocking the cell cycle at G1 and inducing apoptosis. The 4-OHTam does not modify the phosphorylation state of Akt and STAT3, known to be important regulators of proliferation and survival of MM cells (FIG. 2C). The induction of apoptotic cell death is independent of Bcl-2, Bcl-X, and Bax proteins, for which the levels remain unmodified after 4-OHTam treatment. It has been previously proposed that the proapoptotic effect of tamoxifen was due to a positive regulation of the Fas receptor. ${ }^{4}$ The expression of this molecule will be studied, as well as the role of the caspase family in the induction and execution of apoptosis.

\section{ACKNOWLEDGMENTS}

This work was supported by grants from ARERS-Verre Espoir, Fondation de France (No. 2002004328), and Ligue contre le cancer-Comité de la Manche. J. Gauduchon received a Scholar Award from the Académie de Médecine. We thank A. Barbaras and A. Régner for their technical help, and F. Freymuth (Laboratoire de Virologie, CHU de Caen), X. Troussard (Laboratoire d'Hématologie, CHU de Caen), and E. Lebrun (Etablissement Français du Sang, Caen) for their help in the characterization of MM cell lines.

\section{REFERENCES}

1. Hallek, M., P.L. Bergsagel \& K.C. Anderson. 1998. Multiple myeloma: increasing evidence for a multistep transformation process. Blood 91: 3-21.

2. Hideshima, T. \& K.C. Anderson. 2002. Molecular mechanisms of novel therapeutic approaches for multiple myeloma. Nat. Rev. Cancer 2: 927-937.

3. Treon, S.P., G. Teoh, M. Urashima et al. 1998. Anti-estrogens induce apoptosis of multiple myeloma cells. Blood 92: 1749-1757.

4. Otsuki, T., O. Yamada, J. Kurebayashi et al. 2000. Estrogen receptors in myeloma cells. Cancer Res. 60: 1434-1441.

5. Troussard, X., H. Avet-Loiseau, M. Macro et al. 2000. Cyclin D1 expression in patients with multiple myeloma. Hematol. J. 1: 181-185. 